\title{
C-Reactive Protein Levels in Women with Polycystic Ovarian Syndrome and Healthy Controls
}

\section{C-reaktif Protein Düzeylerinin Polikistik Over Sendromlu Kadınlar ile Sağlıklı Kadınlarda Değerlendirilmesi}

\author{
Özgür Yllmaz ${ }^{1}$, Muzaffer Temur ${ }^{* 2}$, Tuncay Küme ${ }^{3}$, Çiğdem Alper Karas ${ }^{4}$, Sefa Kelekçi ${ }^{5}$, Yasemin Kılıç Öztürk
}

\begin{abstract}
Aim/background: Although, pathophysiology of polycystic ovarian syndrome has not been fully understood, insulin resistance may have a pivotal role in this condition. It has been suggested that subclinical inflammation is strongly related to both insulin resistance and obesity associate metabolic disorders. In this study, we aimed to evaluate the serum levels of C-reactive protein which has been determined as an insulin resistance related inflammatory marker and investigate to its potential role the polycystic ovarian syndrome in our study population. Methods: Forty women with polycystic ovarian syndrome and forty age and body mass index matched healthy controls were retrospectively evaluated in this study. Serum fasting glucose, insulin, C-reactive protein and total testosterone concentrations were assessed. Results: Both serum C-reactive protein (1.14 \pm 1.86 $\mathrm{mg} / \mathrm{L}$ vs. $3.56 \pm 4.69 \mathrm{mg} / \mathrm{L} ; \mathrm{p}=0.004)$ and total testosterone concentrations $(\mathrm{p}=0.011)$ were higher in polycystic ovarian syndrome group. $\mathrm{C}$-reactive protein levels significantly and positive correlated with body weight, body mass index and waist circumference $(\mathrm{p}<0.05)$. In the linear regression model, polycystic ovarian syndrome was defined as a dependent variable and hs-CRP was determined as a independent variable. According to this analysis $C$-reactive protein associated with polycystic ovarian syndrome $\left(\beta=0.326, R^{2}=0.106\right.$ and $\left.p=0.003\right)$ Conclusion: Several inflammatory molecules associate with both insulin resistance and obesity related cardio metabolic disorders. However, there are some conflicting results in relationship between polycystic ovarian syndrome and inflammatory molecules including C-reactive protein. Therefore, advanced studies need to explain the potential role of the C-reactive protein in polycystic ovarian syndrome.
\end{abstract}

Key words: Polycystic ovarian syndrome, C-reactive protein, inflammation

ÖZET

Amaç/Giriş: Polikistik over sendromunun (PKOS) patogenezi tam olarak anlaşılamamış olmakla birlikte insülin direncinin bu hastalıkta önemli bir role sahip olabileceği bildirilmiştir. Subklinik inflamasyonun insulin direnci ve obezite ile ilişkili metabolik bozukluklarda önemli bir rol oynadığı düşünülmektedir. Bu çalışmada incelediğimiz populasyonda PKOS'lu ve sağlıklı kadınlar arasında bir inflamatuar belirteç olan C-reaktif protein serum düzeylerini değerlendirerek polikistik over sendromundaki yerini değerlendirmeyi amaçladık. Yöntem: Polikistik over sendromu olan 40 kadın ile vücut kitle indeksi ve yaş açısından eşleştirilmiş olan 40 sağlıklı kadın geriye dönük olarak incelendi. Serum açlık glukoz, insulin, C-reaktif protein (CRP) ve total testosteron düzeyleri değerlendirildi. Bulgular: Serum C-reaktif protein $(1.14 \pm 1.86 \mathrm{mg} / \mathrm{L}$ 'e karşın 3.56 $\pm 4.69 \mathrm{mg} / \mathrm{L}$; $\mathrm{p}=0.004)$ ve serum total testosteron konsantrasyonu $(\mathrm{p}=0.011)$ polikistik over sendromlu kadınlarda anlamlı olarak daha yüksekti. Serum C-reaktif protein ile vücut ağırlı̆̆ı, vücut kitle indeksi ve bel çevresi arasında anlamlı pozitif korelasyon saptandı $(\mathrm{p}<0.05)$. Polikistik over sendromunun bağımlı değişken, C-reaktif proteinin ise bağımsız değişken olarak tasarlandığı lineer regresyon modeli'nin sonuçlarına göre C-reaktif proteinin polikistik over sendromu ile istatistiksel olarak anlamlı seviyede birliktelik gösterdiği saptandı $\left(\beta=0.326, R^{2}=0.106\right.$ ve $\left.p=0.003\right)$ Sonuç: Pek çok inflamatuar molekül insulin direnci ve obezite ile ilişkili metabolik ve kardiyovasküler bozukluklar ile birliktelik gösterir. Ancak polikistik over sendromu ile C-reaktif proteini de içeren inflamatuar moleküller arasındaki ilişkiye ait veriler birbirleri ile tam olarak örtüşmemektedir. Bundan dolayı ileri çalışmalarla C-reaktif proteinin polikistik over sendromundaki rolünün aydınlatılması gereklidir.

Anahtar kelimeler: Polikistik over sendromu, C-reaktif protein, inflamasyon

Received / Geliș tarihi: 30.06.2017, Accepted / Kabul tarihi: 06.09.2017

1 Manisa Merkezefendi Devlet Hastanesi Kadın Hastalıkları ve Doğum Kliniği

2 SBÜ. Bursa Yükses İhtisas Eğitim ve Araştırma Hastanesi Kadın Hastalıkları ve Doğum Kliniği

3 Dokuz Eylül Üniversitesi Tıp Fakültesi Tıbbi Biyokimya Anabilim Dalı

4 izmir Medical Park hastanesi Kadın hastalıkları ve Doğum Kliniği

5 İzmir Katip Çelebi Üniversitesi Tıp Fakültesi Kadın Hastalıkları ve Doğum Anabilim Dalı

6 İzmir Tepecik Eğitim ve Araştırma Hastanesi Aile Hekimliği Kliniği

*Address for Correspondence/ Yazışma Adresi: Muzaffer Temur, SBÜ. Bursa Yükses İhtisas Eğitim ve Araştırma Hastanesi Kadın hastalıkları ve Doğum Kliniği, Bursa / TÜRKIYE, E-mail: drmuzaffer@yahoo.com

Yılmaz Ö, Temur M, Küme T, Karas ÇA, Kelekçi S, Öztürk YK. C-reaktif Protein Düzeylerinin Polikistik Over Sendromlu Kadınlar ile Sağlıklı Kadınlarda Değerlendirilmesi. TJFMPC, 2017; 11(4): 265-270.

DOI: $10.21763 /$ tjfmpc.359835 


\section{GíRIŞ}

Polikistik Over Sendromu (PKOS) kadınlarda en sık görülen endokrinopati olup doğurgan yaşdaki kadınların yaklaşık \%5 ile 10'unu etkiler. Bu bozukluk klinik veya laboratuvar hiperandrojenizm, kronik oligo-veya anovulasyon ve overlerdeki polikistik yapı ile karakterizedir. İnsülin direncinin PKOS daki önemli bir fizyopatolojik faktör olduğu düşünülmektedir. ${ }^{1}$ İnsülin direnci çoğu zaman aterogenez oluşumu ile birliktelik gösterir. PKOS'lu kadınların yarıdan fazlasında değişik derecelerde hiperandrojenemi ve insülin direncinin eşlik ettiği obezite mevcut olup; bu durum ateroskleroz ve hiperglisemi gelişimi yönünden ilave.bir risk faktörüdür. ${ }^{2}$ Obezite, hipertansiyon, dislipidemi ve ateroskleroz gibi bazı metabolik bozukluklarda birçok subklinik inflamasyon belirteçin düzeylerinde artış olduğu saptanmıştır. Hiperglisemi periferal mononükleer hücrelerden reaktif oksijen türlerinin salınımına yol açmasından dolayı proinflamatuar etki gösterir. ${ }^{3}$ PKOS daki obezite ve insülin direnci sıklığındaki artış hipertansiyon, lipid profilinde bozukluklar, insülin direnci, gestasyonel ve tip 2 diabetes mellitus ve nihayetinde artmış kardiyovasküler morbidite riski gibi bir çok hastalığa zemin hazırlar. ${ }^{4}$

Biz bu çalışmada insülin direnci ve kardiyovasküler risk durumunu yansıtan inflamatuar moleküllerden biri olan C-reaktif protein (CRP)' in ${ }^{5,6}$ serum düzeylerini PKOS'lu kadınlar ile ek sağlık problemi olmayan kadınlar arasında karşılaştırarak PKOS daki yerini incelemeyi amaçladık.

\section{YÖNTEM}

$\mathrm{Bu}$ retrospektif çalışma Manisa Merkezefendi Devlet Hastanesi Kadın Hastalıkları ve Doğum Polikliniği'ne başvuran kadınlar arasında hastalara ait veri kayıtlarının bu hastanede kullanılan yazılım sisteminin (Probel Bilgisayar Yazılım Donanım San. Tic. Ltd. Şti, İzmir, Türkiye) geriye yönelik incelenmesi ile elde edildi. 18 ile 38 yaş arasındaki Polikistik over sendromlu kırk, 18 ile 38 yaş arasındaki normal menstrüel sikluslu kırk olmak üzere toplam seksen olgunun kayıtları incelendi. Polikistik Over Sendromu tanısı kronik oligomenore (Yıllık menstruasyon sayısının altı veya daha az sayida olmas1), serum total testosteron konsantrasyonundaki yükseklik olarak tanımlanan biyokimyasal hiperandrojenizm, yapılan klinik değerlendirmede hiperandrojenizme yol açacak başka klinik tablonun bulunmaması ve pelvik ultrasonografide polikistik ovarian morfoloji (her iki overde $0.8-1.2 \mathrm{~cm}$ büyüklüğünde çevresel yerleşimli on adet ve üzeri kistler) saptanması kriterlerine göre konuldu. $^{7}$ İnsülin direnci ise insülin direnci homeostatik model değerlendirmesi indeksinin(homeostasis model assessment of insulin resistance - HOMA-IR) belirtilen şu formülüne göre hesapland1: HOMA-IR= (serum açlık insulin $(\mathrm{mU} / \mathrm{mL}) X$ serum açlık glukoz $(\mathrm{mg} / \mathrm{dL})) / 405{ }^{8}$ Menstrüel siklus düzeni normal, pelvik ultrasonografi değerlendirmesinde overlerde polikistik morfoloji olmayan ve serum total testosteron düzeyi normal sınırlar içinde bulunan olgular yaş ve vücut kitle indeksi (VKİ) kıyaslamalı olarak sağlıklı gruba dahil edildi. Gebe kadınlar, erken menopoz dönemindeki kadınlar, emzirenler, tanı konulmuş hipertansiyon, diabetes mellitus, adrenal gland hastalığ anamnezde aktif enfeksiyonu olanlar, antibiyotik tedavisi alanlar çalışmaya dahil edilmedi. Bu retrospektif çalışma etik kurul onayı (Dokuz Eylül Üniversitesi Girişimsel Olmayan Araştırmalar Etik Kurulu; 18.02.2016, Karar no: 2016/05-27) alınmasının ardından gerçekleştirildi.

İstatistiksel analizler SPSS v.15.0 (SPSS Inc.Chicago, IL, ABD) bilgisayar programı kullanılarak yapıldı. Değişkenler ortalama \pm standart sapma (SD), şeklinde ifade edildi. Değişkenlerin kıyaslanması nda bağımsız örneklem t-testi kullanıldı. Değişkenlerin birbirleri arasındaki korelasyonlar Pearson'nun korelasyon analizi ile değerlendirildi. Değişkenlerin birbirleri arasındaki sebep-sonuç ilişkileri ise lineer regresyon analizi ile değerlendirildi. Güç (Power) analizi Windows işletim sistemine uygun $\mathrm{G}^{*}$ Power 3.0.10 bilgisayar programı (Heinrich-Heine-Universität Düsseldorf, Düsseldorf, Almanya) kullanılarak yapıldı. P değerinin $<0.05$ olması anlamlı olarak kabul edildi.

\section{BULGULAR}

Çalışma popülasyonuna ait klinik ve laboratuvar bulguları Tablo 1'de gösterilmistir. Her iki grup arasında yaş $(\mathrm{p}=0.093)$, boy $(\mathrm{p}=0.443)$, vücut ağırlığ 1 $(p=0.174)$, VKI $(p=0.277)$, bel çevresi $(p=0.629)$ ve kalça çevresi $(p=0.057)$ yönünden anlamlı fark bulunmadı. Gruplar arasında serum açlık glukoz ( $p=0.667)$, ve insülin $(p=0.442)$ ve HOMA-IR $(p=0.422)$ değerleri arasında anlamlı fark saptanmadi. Serum CRP $(1.14 \pm 1.86 \mathrm{mg} / \mathrm{L}$ 'e karşın $3.56 \pm 4.69 \mathrm{mg} / \mathrm{L} ; \mathrm{p}=0.004)$ ve serum total testosteron konsantrasyon'u $\quad(0.366 \pm 0.149 \mathrm{ng} / \mathrm{mL}$ 'e $\quad$ karşın $0.467 \pm 0.196 \mathrm{ng} / \mathrm{mL} ; \mathrm{p}=0.011)$ ise PKOS' lularda anlamlı olarak daha yüksek saptandı.

PKOS'lu kadınlar, kontrol grubu ve tüm çalışma popülasyonundaki CRP ile klinik ve laboratuvar bulgular arasındaki ilişkiyi inceleyen Pearson'un korelasyon analizi sonuçları tablo 2'de 


\begin{tabular}{|c|c|c|c|}
\hline & Kontrol $(n=40)$ & PKOS $(n=40)$ & P değeri \\
\hline Yaş (yıl) & $25.95 \pm 5.335$ & $23.58 \pm 7.038$ & 0.093 \\
\hline Boy $(\mathrm{cm})$ & $160.89 \pm 5.498$ & $162.18 \pm 9.018$ & 0.443 \\
\hline Vücut Ağırlığg (kilogram) & $65.692 \pm 11.722$ & $70.57 \pm 19.135$ & 0.174 \\
\hline Vücut Kitle İndeksi $\left(\mathrm{kg} / \mathrm{m}^{2}\right)$ & $25.456 \pm 4.818$ & $26.011 \pm 7.564$ & 0.277 \\
\hline Bel çevresi (cm) & $84.675 \pm 10.661$ & $86.175 \pm 16.372$ & 0.629 \\
\hline Kalça Çevresi $(\mathrm{cm})$ & $104 \pm 9.438$ & $109.82 \pm 16.473$ & 0.057 \\
\hline Serum Açlık Glukoz(mg/dL) & $87.425 \pm 4.511$ & $88 \pm 7.103$ & 0.667 \\
\hline Serum Açlık İnsülin $(\mu \mathrm{U} / \mathrm{ml})$ & $12.772 \pm 5.212$ & $13.863 \pm 7.251$ & 0.442 \\
\hline $\begin{array}{l}\text { Serum } \\
\text { Testosteron }(\mathrm{ng} / \mathrm{mL})\end{array}$ & $0.366 \pm 0.149$ & $0.467 \pm 0.196$ & 0.011 \\
\hline HOMA-IR & $2.751 \pm 1.106$ & $2.987 \pm 1.479$ & 0.422 \\
\hline Serum CRP(mg/L) & $1.135 \pm 1.86$ & $3.56 \pm 4.69$ & 0.004 \\
\hline
\end{tabular}

Bağımsız örnekler için t-testi kullanıldı. Değiskenler ortalama \pm standart sapma seklinde ifade edildi. P değerinin 0.05 'den küçük olması anlamlı kabul edildi. Kısaltmalar: HOMA-IR: homeostasis model assessment of insulin resistance; CRP: C-reaktif protein; PKOS: Polikistik Over Sendromu.

Tablo 2. Kontrol grubu, PKOS grubu ve tüm çalışma populasyonunda, CRP ile klinik ve laboratuvar verileri arasındaki ilişkileri ayrı ayrı inceleyen korelasyon analizi sonuçları

\begin{tabular}{|c|c|c|c|c|}
\hline & & Kontrol Grubu & PKOS Grubu & $\begin{array}{l}\text { Tüm Çalışma } \\
\text { Populasyonu }\end{array}$ \\
\hline \multirow[t]{2}{*}{ Yaş (y1l) } & $r$ & -0.068 & 0.289 & 0.123 \\
\hline & $P$ & 0.675 & 0.07 & 0.276 \\
\hline \multirow[t]{3}{*}{ Boy $(\mathrm{cm})$} & $r$ & -0.134 & 0.084 & 0.067 \\
\hline & $P$ & 0.41 & 0.606 & 0.555 \\
\hline & $r$ & 0.384 & 0.614 & 0.574 \\
\hline \multirow[t]{2}{*}{ Vücut Ağırlığı (kilogram) } & $P$ & 0.014 & $<0.001$ & $<0.001$ \\
\hline & $r$ & 0.41 & 0.551 & 0.522 \\
\hline \multirow{2}{*}{ Vücut Kitle İndeksi(kg/m²) } & $P$ & 0.009 & $<0.001$ & $<0.001$ \\
\hline & $r$ & 0.385 & 0.566 & 0.507 \\
\hline Bel çevresi (cm) & $P$ & 0.014 & $<0.001$ & $<0.001$ \\
\hline \multirow[t]{3}{*}{ Kalça Çevresi (cm) } & $r$ & 0.203 & 0.485 & 0.466 \\
\hline & $P$ & 0.209 & 0.002 & $<0.001$ \\
\hline & $r$ & 0.386 & 0.303 & 0.216 \\
\hline Bel/Kalça oranı & $P$ & 0.014 & 0.058 & 0.055 \\
\hline \multirow[t]{2}{*}{ Serum Açlık Glukoz(mg/dL) } & $r$ & 0.06 & 0.061 & 0.062 \\
\hline & $P$ & 0.973 & 0.709 & 0.585 \\
\hline \multirow[t]{2}{*}{ Serum Açlık İnsülin $(\mu \mathrm{U} / \mathrm{ml})$} & $r$ & 0.18 & 0.151 & 0.173 \\
\hline & $P$ & 0.266 & 0.351 & 0.126 \\
\hline \multirow[t]{2}{*}{ HOMA-IR } & $r$ & 0.207 & 0.149 & 0.177 \\
\hline & $P$ & 0.2 & 0.359 & 0.116 \\
\hline Serum & $r$ & -0.105 & -0.216 & -0.074 \\
\hline Testosteron(ng/mL) & $P$ & 0.52 & 0.18 & 0.512 \\
\hline
\end{tabular}



gösterilmiştir. PKOS'lu kadınlar, kontrol grubu ve tüm çalışma populasyonunda CRP ile yaş, boy, bel/kalça oranı, serum açlık glukoz, serum açlık insülin, HOMA-IR ve serum total testosteron düzeyleri arasında anlamlı korelasyon saptanmadı ( $>>0.05)$. Her üç grupta da CRP ile vücut ağırlığı, VKI ve bel çevresi arasında anlamlı pozitif korelasyon saptand $1(\mathrm{p}<0.05)$.

Tüm çalışma populasyonunda CRP ile kalça çevresi arasında anlamlı pozitif korelasyon saptand $1(r=0.466 ; p<0.001)$. Gruplar ayr1 ayr1 incelendiğinde ise PKOS grubunda da CRP ile kalça çevresi arasında anlamlı pozitif korelasyon saptanır iken $(\mathrm{r}=0.485$; $\mathrm{p}=0.02)$; kontrol grubunda bu anlamlı ilişki mevcut değildi $(r=0.203 ; p=0.209)$.

PKOS ile CRP düzeyleri arasındaki potansiyel birlikteliği incelemek amacı ile lineer regresyon modeli oluşturuldu. $\mathrm{Bu}$ modele göre PKOS bağımlı değişken, serum CRP düzeyleri ise bağımsız değişken olarak tasarlandı. Bu analizin sonuçlarına göre CRP düzeyleri PKOS ile anlamlı düzeyde birliktelik gösteriyordu $(\beta=0.326$; $\left.\mathrm{R}^{2}=0.106 ; \mathrm{p}=0.003\right)$. Çalışmamızın retrospektif olarak planlanmas1; ayrica olgu ve kontrol gruplarının birbirleri arasında yaş ile VKI eşleşmeli olarak oluşturulmasından ötürü, örneklem büyüklügüumüz toplam olarak 80 kadın ile sınırlı kaldı. Bu sayı ile yapılan power (güç) analizinde çalışmamızın gücü 0.598 olarak hesaplandı $(\alpha-$ hata $=0.05 ; \mathrm{d}=0.5)$.

\section{TARTIŞMA}

$\mathrm{Bu}$ retrospektif çalışmada PKOS'lu kadınlarda serum CRP düzeyleri yaş ve VKI eşleşmeli kontrol grubuna kıyasla anlamlı olarak yüksek bulunur iken; CRP düzeyleri ile obezite belirteçleri arasında anlamlı pozitif ilişki saptandı. Ayrıca CRP düzeyleri PKOS ile anlamlı olarak birliktelik göstermekte idi.

PKOS'dan etkilenen kadınlarda insülin duyarlılığı obeziteden bağımsız olarak yaklaşık \%35-40 oranında azalır ve bu miktar tip 2 diabetes mellitus'lu hastalardaki insülin duyarlılığındaki azalma miktarına yakındır. Bununla beraber obezitenin oluşturduğu metabolik yükün insülin faaliyetini daha da bozması ile PKOS'lu kadınların yaklaşık \%50 ile \%70'inde çeşitli düzeylerde insülin direnci mevcuttur. İnflamatuar sürecin ateroskleroz ve diyabet gibi obezite ve insulin direnci ilişkili metabolik bozuklukların altında yatan sebeplerinden biri olabileceği düşünülmektedir. Polikistik over sendromu da insülin direnci ve obezite ilişkili metabolik bozukluklardan birisi olarak kabul edilir. ${ }^{\text {- }}$ ${ }^{3}$ Ancak PKOS ile inflamasyon arasındaki ilişkiye ait sonuçlar tip 2 diyabet ve kardiyovaskuler hastalıklarda olduğu kadar belirgin farklılıklar sergiler. İlk olarak PKOS'lularda CRP düzeylerinde artış bildiren çalışmaların bile kendi aralarında belirli yönlerden farklılıkları mevcuttur. Örnek olarak El-Mesallamy ve arkadaşları yaş ve obezite düzeyleri benzer olan Misır'lı PKOS'lu kadınlarda kontrollere kıyasla CRP'nin yüksek olduğunu buldular. Ve bu yükseklik de obeziteden bağımsız olarak insulin direnci ile birliktelik gösterdiğini bildirdiler. ${ }^{9}$ Sumithra ve arkadaşları Hindistan'da yaşları 18-40 arasında değişen VKI eşleşmeli PKOS lu kadınlarda CRP düzeylerini kontrollere kıyasla anlamlı yüksek buldular. Fakat onlar bu durumun PKOS'da artmış olan oksidatif stresden kaynaklandığını bildirdiler ${ }^{10}$

Çalışmamızda CRP düzeyleri ile vücut ağırlığı, VKI, bel çevresi,ve bel/kalça oranı gibi obezite belirteçleri arasında anlamlı korelasyon var iken; ilave olarak CRP düzeyleri PKOS ile de anlamlı birliktelik gösteriyordu. $\mathrm{Bu}$ bulgular incelediğimiz populasyondaki hs-CRP düzeylerinin hem obezite hem de PKOS ile ilişkili olduğunu düşündürmektedir. Puder ve arkadaşları PKOS'lulardaki CRP ve diğer inflamatuar belirteçlerin düzeylerindeki yüksekliklerin PKOS durumundan ziyade atmış santral obezite ile birliktelik gösterdiğini bildirmişlerdir. ${ }^{11}$ Ganie ve arkadaşları ise adölesanları inceledikleri çalışmalarında PKOS‘lular ile yaş ve VKI kıyaslamalı kontroller arasında serum CRP konsantrasyonları yönünden anlamlı fark bulamamışlardır. Bununla beraber CRP düzeyleri ile VKI ve bel çevresi gibi obezite belirteçleri arasında anlamlı pozitif korelasyon olduğunu bildirmişlerdir. 12

İnterlökin-6 (IL-6) ve aynı zamanda adipoz doku tarafindan da fazla miktarda eksprese edilen tümör nekrosis faktör-alfa (TNF- $\alpha$ ) gibi bazı inflamatuar moleküller insülinin hedef dokularındaki akut ve kronik etkileri ile insülin direncini teşvik ederler. ${ }^{3}$ PKOS ve inflamatuar belirteçler arasındaki ilişkiye ait farklı sonuçlar sadece CRP için değil aynı zamanda diğer inflamatuar moleküller içinde mevcuttur. PKOS'lu kadınlar yaş ve VKI eşleşmeli kontrollerle karşılaştırıldığında dolaşımdaki TNF- $\alpha$, IL-6, ve CRP düzeylerinde artış olduğu bildirilmiştir. 13,14 Ancak başka çalışmalarda ilginç olarak obez PKOS' lular ile obez kontroller arasinda TNF- $\alpha$ ile IL-6 yönünden farklılık olmadığı bildirilmiştir. ${ }^{15,16}$

PKOS'lu hastalardaki metabolik ve kardiyovasküler risklerdeki artışın sebeplerinden birisinin de hastalığın temel bulguları arasında yer alan hiperandrojenizm olabileceği öne sürülmektedir. ${ }^{17-19}$ Çalışmamızda hiperandrojenizmi 
tanımlamakta kullandığımız serum total testosteron düzeyleri ile CRP arasında anlamlı pozitif korelasyon bulduk. Öte yandan Ganie ve arkadaşları adölesan yaş grubunu inceledikleri çalışmalarında serum CRP ile serum total testosteron düzeyleri arasında anlamlı korelasyon olmadığını ve laboratuvar hiperandrojenizm'in PKOS lu kadınlarda var olan düşük dereceli inflamasyon ile ilişkili olmayabileceğini bildirmişlerdir. ${ }^{12}$

Çalışmamızda bazı kısıtlıklar mevcuttu. İlk olarak olgu ve kontrol gruplarının birbirleri arasında yaş ile VKI eşleşmeli olarak oluşturulmasından dolayı çalışma populasyonumuz nispeten küçük idi. İkinci olarak çalışmamız geriye yönelik tipte bir çalışma idi. Son olarak ise CRP dıșındaki TNF- $\alpha$ ve IL-6 gibi insulin direnci ve obezite ile birlikteliği olan diğer inflamatuar belirteçlerin serum düzeylerini değerlendiremedik.

\section{SONUÇ}

Retrospektif olarak yaptı̆̆ımız çalışmamızda PKOS'lu hastalarda bir inflamatuar belirteç olan CRP konsantrasyonlarını yaş ve VKI eşleştirmeli kontrollerle karşılaştırdığımızda anlamlı olarak daha yüksek bulduk. CRP düzeyleri PKOS ile anlamlı birliktelik gösterir iken; obezite belirteçleri ile de arasında anlamlı korelasyon mevcuttu. Aralarında CRP'nin de bulunduğu inflamatuar moleküller insulin direnci ve obezite ilişkili metabolik bozukluklar ile birliktelik gösterirler. Günlük pratiğimizde özellikle birinci basamak merkezlerde PKOS tanısını desteklemek amaciyla hassas-CRP nin de tetkiklere eklenebileceği ancak bu konuda daha kapsamlı çalışmalara ihtiyaç olduğu görüşündeyiz.

\section{ÇIKAR ÇATIŞMASI}

Yazarlar bu yazının hazırlanması ve yayınlanması aşamasında herhangi bir çıkar çatışması olmadığını beyan etmişlerdir.

\section{KAYNAKLAR}

1. Mukherjee S, Maitra A. Molecular \& genetic factors contributing to insulin resistance in polycystic ovary syndrome. Indian J Med Res. 2010; 131:743-60.

2. Majumdar A, Singh TA. Comparison of clinical features and health manifestations in lean vs. obese Indian women with polycystic ovarian syndrome. J Hum Reprod Sci. 2009; 2:12-17.

3. Sathyapalan T, Atkin SL. Mediators of inflammation in polycystic ovary syndrome in relation to adiposity. Mediators Inflamm. 2010; 2010:758656

4. Diamanti-Kandarakis E, Christakou CD, Kandaraki E, Economou FN. Metformin: an old medication of new fashion: evolving new molecular mechanisms and clinical implications in polycystic ovary syndrome.Eur J Endocrinol. 2010; 162:193-212.

5. Ridker PM. Clinical application of C-reactive protein for cardiovascular disease detection and prevention. Circulation. 2003; 107:363-369.

6. Oemrawsingh RM, Cheng JM, Akkerhuis KM, Kardys I, Degertekin M, van Geuns RJ et al. High-sensitivity C-reactive protein predicts 10-year cardiovascular outcome after percutaneous coronary intervention. EuroIntervention. 2016 Jun 20;12(3):345-51

7. Legro RS, Arslanian SA, Ehrmann DA, Hoeger KM, Murad MH, Pasquali R, Welt CK; Endocrine Society. Diagnosis and treatment of polycystic ovary syndrome: an endocrine society clinical practice guideline. J Clin Endocrinol Metab 2013;12: 4565-4592

8. Matthews DR, Hosker JP, Rudenski AS, Naylor BA, Treacher DF, Turner RC. Homeostasis model assessment: insulin resistance and betacell function from fasting plasma glucose and insulin concentrations in man. Diabetologia 1985; 28:412-419

9. El-Mesallamy HO, Abd El-Razek RS, ElRefaie. TA.Circulating high-sensitivity Creactive protein and soluble CD40 ligand are inter-related in a cohort of women with polycystic ovary syndrome.Eur J Obstet Gynecol Reprod Biol. 2013; 168:178-182.

10. Sumithra NU, Lakshmi RL, Leela Menon N, Subhakumari KN, Sheejamol VS. Evaluation of oxidative stress and hsCRP in polycystic ovarian syndrome in a tertiary care hospital.Indian J Clin Biochem. 2015; 30:161166.

11. Puder JJ, Varga S, Kraenzlin M, De Geyter C, Keller U, Müller B. Central fat excess in polycystic ovary syndrome: relation to lowgrade inflammation and insulin resistance.J Clin Endocrinol Metab. 2005; 90:6014-6019

12. Ganie MA, Hassan S, Nisar S, Shamas N, Rashid A, Ahmed I, et al. High-sensitivity Creactive protein (hs-CRP) levels and its relationship with components of polycystic 
ovary syndrome in Indian adolescent women with polycystic ovary syndrome (PCOS). Gynecol Endocrinol. 2014; 30:781-784.

13. Kelly CC, Lyall H, Petrie JR, Gould GW, Connell JM, Sattar N. Low grade chronic inflammation in women with polycystic ovarian syndrome. J Clin Endocrinol Metab. 2001; 86:2453-2455.

14. Amato G, Conte M, Mazziotti G, Lalli E, Vitolo G, Tucker AT, et al. Serum and follicular fluid cytokines in polycystic ovary syndrome during stimulated cycles.Obstet Gynecol. 2003;101:1177-1182

15. Gonzalez F, Thusu K, Abdel-Rahman E, Prabhala A, Tomani M, Dandona P. Elevated serum levels of tumor necrosis factor alpha in normal-weight women with polycystic ovary syndrome. Metabolism. 1999; 48:437-441.

16. Escobar-Morreale HF, Villuendas G, BotellaCarretero JI, Sancho J, San Millán JL. Obesity, and not insulin resistance, is the major determinant of serum inflammatory cardiovascular risk markers in pre-menopausal women. Diabetologia. 2003; 46:625-633

17. Chen MJ, Yang WS, Yang JH, Chen CL, Ho HN, Yang YS. Relationship between androgen levels and blood pressure in young women with polycystic ovary syndrome. Hypertension. 2007; 49:1442-1447

18. Luque-Ramírez M, Martí D, Fernández-Durán E, Alpañés M, Álvarez-Blasco F, EscobarMorreale HF. Office blood pressure, ambulatory blood pressure monitoring, and echocardiographic abnormalities in women with polycystic ovary syndrome: role of obesity and androgen excess. Hypertension 2014;63:624629.

19. Kim MJ, Lim NK, Choi YM, Kim JJ, Hwang KR, Chae SJ, et al. Prevalence of metabolic syndrome is higher among non-obese PCOS women with hyperandrogenism and menstrual irregularity in Korea. PLoS One. 2014 Jun 5;9(6):e99252. 